\title{
Primary open angle glaucoma genetics: The common variants and their clinical associations (Review)
}

\author{
ALEXANDRA TRIVLI ${ }^{1}$, MARIA I. ZERVOU ${ }^{1}$, GEORGE N. GOULIELMOS $^{1}$, \\ DEMETRIOS A. SPANDIDOS ${ }^{2}$ and EFSTATHIOS T. DETORAKIS ${ }^{3}$
}

\author{
${ }^{1}$ Section of Molecular Pathology and Human Genetics, Department of Internal Medicine, \\ School of Medicine; ${ }^{2}$ Laboratory of Clinical Virology, Medical School, University of Crete, 71003 Heraklion; \\ ${ }^{3}$ Department of Ophthalmology, University Hospital of Heraklion, 71110 Heraklion, Greece
}

Received February 25, 2020; Accepted June 3, 2020

DOI: $10.3892 / \mathrm{mmr} .2020 .11215$

\begin{abstract}
Glaucoma is a group of progressive optic neuropathies that have in common characteristic optic nerve head changes, loss of retinal ganglion cells and visual field defects. Among the large family of glaucomas, primary open-angle glaucoma (POAG) is the most common type, a complex and heterogeneous disorder with environmental and genetic factors contributing to its pathogenesis. Approximately 5\% of POAG is currently attributed to single-gene or Mendelian forms of glaucoma. Genetic linkage analysis and genome-wide association studies have identified various genomic loci, paving the path to understanding the pathogenesis of this enigmatic, blinding disease. In this review we summarize the most common variants reported thus far and their possible clinical correlations.
\end{abstract}

\section{Contents}

1. Introduction

2. Search strategy

3. Genomic loci

4. Common variants

5. Additional genes associated with POAG

6. Endophenotypes and clinical association

7. Conclusion

\section{Introduction}

Glaucoma represents a group of chronic and progressive optic neuropathies with distinctive pattern of progressive

Correspondence to: Dr Alexandra Trivli, Section of Molecular Pathology and Human Genetics, Department of Internal Medicine, School of Medicine, 71003 Heraklion, Greece

E-mail: alextrivli@yahoo.com

Key words: glaucoma, primary open-angle glaucoma, genome-wide association studies, endophenotype, linkage, genetics visual field loss and optic disc damage, and is the leading cause of irreversible blindness worldwide. This enigmatic and heterogeneous disease has affected $3.5 \%$ of the world's population with approximately 5.7 million people visually impaired and 3.1 million blind, and an estimate to affect 111.8 million people by 2040 (1). Primary open-angle glaucoma (POAG), the most common representative, is characterized by a normal, open anterior chamber angle and elevated intraocular pressure (IOP) or even normal IOP, named normal tension glaucoma (NTG). Two hallmark theories attempt to explain the pathway of the disease; the mechanical and vascular theory. Although both present postulated mechanisms of progressive retinal ganglion cell (RGC) damage and eventual optic neuropathy, the exact etiology still remains unknown (2). The well recognised risk factors for POAG include higher age, high IOP, decreased central corneal thickness (CCT), African descent, high myopia and a positive family history $(3,4)$. Amongst them, high IOP remains the only modifiable risk factor for the development and prognostic factor for the progression of POAG (3).

POAG has long shown a strong genetic component with $60 \%$ of patients with a positive family history and family based studies identifying a 10 -fold increased risk of POAG for first degree relatives (5). Heritability of POAG can be divided into two major categories: direct association (increased POAG risk) and indirect (increased risk for a component of the disease). The first one deals with several genes linked to POAG through family-based genetic linkage analysis, with major examples being myocilin (MYOC), optineurin (OPTN), WD repeat domain 36 (WDR36), cytochrome P450, family 1 , subfamily B, polypeptide 1 (CYP1B1) and neurotrophin 4 (NTF4) (6-10). With heritability ranging from 0 (no genetic component) to 1 (phenotype determined by genes), these genes attribute to POAG heritability at 0.81 (11). The second factor refers to the endophenotype traits related to POAG pathogenesis, highly heritable and polymorphic. Notable examples are IOP (0.55), vertical cup-to-disc ratio (VCDR=0.48-0.66), CCT $(0.72)$, cup area $(\mathrm{CA}=0.75)$ and disc area $(\mathrm{DA}=0.72)(12,13)$.

Genome-wide association studies (GWAS) have been used in the past decade in an attempt to uncover genetic variants of complex diseases. For POAG, over 70 single-nucleotide polymorphisms (SNPs) have been identified and linked to 
POAG or its endophenotypes, changing our understanding of the molecular pathways of the disease (14). Identification of the genes associated with the disease may also provide useful information for both patients and their physicians, by enabling the design of genetic screening tests that may help physicians assess the risk of patients for disease as well as to differentiate between clinically similar disorders. Valuable research available has provided details for many SNPs related to POAG. In this review the authors summarize the most common variants, present their possible clinical correlations and highlight their interactions.

\section{Search strategy}

A MEDLINE/PubMed search was performed for articles in English from January 2010 to January 2020. Keywords included glaucoma, primary open angle glaucoma, genetics, genetic association studies, GWAS and SNP. Further search was performed in the database upon relative findings in the articles.

\section{Genomic loci}

Genetic linkage analysis was the first genetic decoding of glaucoma. Classically used for Mendelian traits or mutations in a single gene, this method reveals chromosomal regions associated with a specific phenotype. Followed by GWAS in various populations, a number of variants and interactions unfolded, thus forming the complicated image of POAG. These genomic loci are marked GLC1A through GLC1P and show high heterogeneity $(14,15)$ (Table I).

\section{Common variants}

Although a number of SNPs has been linked to POAG, those summarized in Table II, appear to be the most commonly studied in the literature.

MYOC/trabecular meshwork-induced glucocorticoid response protein (TIGR). Located on chromosome 1q24, $M Y O C$ encodes protein MYOC, which is believed to have a role in cytoskeletal function and represents the first gene to be associated with POAG (14). Mutations in MYOC (alternatively $T I G R$ ) are linked to the GLC1A locus $(14,16)$. Over 100 POAG-associated mutations have been identified in the MYOC gene making it accountable for 3-5\% of POAG cases (15). Primarily associated with juvenile-onset POAG, expresses an autosomal dominant and highly penetrant severe phenotype, with highly elevated IOP which often requires surgical management $(10,17)$. A less severe form is observed in the adult onset form, the most prevalent one (10). Other associations include primary congenital glaucoma (18). The effect of $M Y O C$ mutations appears to be on the trabecular meshwork (TM) and aqueous humor outflow (19).

CYP1B1. Located on chromosome 2p22.2, CYP1B1 belongs to the cytochrome P450 superfamily of enzymes. Mutations in $C Y P 1 B 1$, although classically linked to anterior segment dysgenesis and congenital glaucoma, may also contribute to the GLC1A phenotype through a digenic inheritance, acting as a modifier for $M Y O C$ (20).

OPTN. Located on chromosome 10p13, OPTN encodes the coiled-coil containing protein OPTN that plays an important role in the maintenance of the Golgi complex, in membrane trafficking and exocytosis. Mutations in OPTN are linked to the GLC1E locus. Even though variable mutations have been recognised, E50K has been strongly linked to glaucoma (21). Primarily associated with NTG, it has also been reported in patients with amyotrophic lateral sclerosis (ALS) (22). A variety of interactions and cellular effects have been reported for $O P T N$, notably its role in autophagy and apoptosis $(23,24)$. It has been reported that although $M Y O C$ overexpression has no effect on $O P T N$ expression, $O P T N$ overexpression upregulates endogenous $M Y O C$ in TM cells (25). Noteworthy, the most notable is the interaction of $O P T N$ with TANK-binding kinase $1(T B K 1)$ as they may share a common pathway $(23,26)$.

TBK1. Located on chromosome $12 \mathrm{q} 14$, mutations in TBK1 are linked to the GLC1P locus (10). Responsible for approximately $1 \%$ of NTG through a copy number variant (CNV) consisting of duplications in the $T B K 1$, mutations have also been reported in patients with ALS and other central nervous system disorders $(22,27,28)$. TBK1 is a kinase that regulates the expression of genes in the $\mathrm{NF}-\kappa \mathrm{B}$ signaling pathway, playing an essential role in regulating inflammatory responses to foreign agents and is also implicated in autophagy (29).

WDR36. Located on chromosome 5q22, WDR36 encodes a member of the WD repeat protein family that is involved in T-cell activation. Mutations in WDR36 are linked to the GLC1G locus (10). Linked to an increased risk for POAG, mutations in WDR36 were initially reported to be responsible for 1.6 to $17 \%$ of POAG $(8,30,31)$. WDR36 appears to negatively affect TM cells via apoptotic cell death (32).

NTF4. Located on chromosome 19q13.33, NTF4 encodes a neurotrophic factor that signals predominantly through the tyrosine kinase receptor B (TrkB) receptor tyrosine kinase. Mutations in NTF4 are linked to the GLC1O locus. Negatively affecting the activation of TrkB, NTF4 mutations have been found in $1.7 \%$ of POAG patients in a study of European patients (9).

Ankyrin repeat and SOCS box containing 10 (ASB10). Located on chromosome 7q36, ASB10 encodes a protein that is a member of the ASB family of proteins. Mutations in ASB10 are linked to the GLC1F locus (33). ASB10 transcription appears to reduce aqueous humor outflow facility (34).

Atonal bHLH transcription factor 7 (ATOH7). Located on chromosome 10q21, ATOH7 encodes a transcription factor that appears to play a role in the differentiation of the RGCs and determination of DA, possibly during embryogenesis. It is associated with DA, VCDR, CA and POAG risk $(35,36)$.

Caveolin 1/caveolin2 (CAV1/CAV2). Located on chromosome 7q31, CAVs are involved in a number of cellular processes such as transcellular transport, cell proliferation 
Table I. Glaucoma genomic loci (GLC1A-P), candidate genes and locations and their associated glaucoma type.

\begin{tabular}{llll}
\hline Locus & Gene & Location & Glaucoma type \\
\hline GLC1A & $M Y O C$ & $1 \mathrm{q} 24.3-\mathrm{q} 25.2$ & POAG/JOAG \\
GLC1B & - & $2 \mathrm{cen}-\mathrm{q} 13$ & POAG, early onset \\
GLC1C & - & $3 \mathrm{q} 21-\mathrm{q} 24$ & POAG \\
GLC1D & - & $8 \mathrm{q} 23$ & POAG, early onset \\
GLC1E & OPTN & $10 \mathrm{p} 13$ & POAG/NTG \\
GLC1F & $A S B 10$ & $7 \mathrm{q} 36$ & POAG \\
GLC1G & WD 36 & $5 \mathrm{q} 22$ & POAG \\
GLC1H & - & $2 \mathrm{p} 16-\mathrm{p} 15$ & POAG \\
GLC1I & - & $15 \mathrm{q} 11-\mathrm{q} 13$ & POAG \\
GLC1J & - & $9 \mathrm{q} 22$ & JOAG \\
GLC1K & - & $20 \mathrm{p} 12$ & JOAG \\
GLC1L & - & $3 \mathrm{p} 22-\mathrm{p} 21$ & POAG \\
GLC1M & - & $5 \mathrm{q} 22$ & JOAG \\
GLC1N & - & $15 \mathrm{q} 22-\mathrm{q} 24$ & JOAG \\
GLC1O & $N T F 4$ & $19 \mathrm{q} 13.3$ & POAG \\
GLC1P & Possibly TBK1 & $12 \mathrm{q} 24$ & POAG \\
\hline
\end{tabular}

MYOC, myocilin; OPTN, optineurin; ASB10, ankyrin repeat and SOCS box containing 10; WDR36, WD repeat domain 36; NTF4, neurotrophin 4; TBK1, TANK-binding kinase 1.

Table II. Candidate genes and their possible association to glaucoma pathogenesis.

\begin{tabular}{|c|c|c|}
\hline Gene & Location & Possible glaucoma mechanism/effect \\
\hline MYOC/TIGR & $1 \mathrm{q} 24$ & TM, outflow ${ }^{\mathrm{a}}$ \\
\hline$C Y P 1 B 1$ & $2 \mathrm{p} 22.2$ & Anterior segment dysgenesis \\
\hline OPTN & $10 \mathrm{p} 13$ & Autophagy, apoptosis \\
\hline$T B K 1$ & $12 q 14$ & Autophagy, inflammatory response \\
\hline WDR36 & $5 q 22$ & TM via apoptosis \\
\hline NTF4 & $19 q 13.33$ & Impaired neuronal survival \\
\hline$A S B 10$ & $7 q 36$ & Outflow \\
\hline ATOH7 & $10 q 21$ & DA, VCDR, CA, POAG risk \\
\hline$C A V 1 / C A V 2$ & $7 q 31$ & IOP changes, outflow \\
\hline$C D K N 2 B-A S 1$ & $9 \mathrm{p} 21$ & VCDR \\
\hline SIX6 & $14 q 23$ & VCDR, myopia, reduced RNFL thickness \\
\hline TMCO1 & $1 q 24.1$ & IOP changes, increased POAG risk \\
\hline$A B C A 1$ & $9 q 31$ & Inflammatory response, neurodegeneration \\
\hline$A F A P 1$ & $4 \mathrm{p} 16.1$ & Unknown \\
\hline ARHGEF 12 & $11 \mathrm{q} 23.3$ & IOP changes, outflow \\
\hline TXNRD2 & $22 q 11$ & Oxidative stress \\
\hline FOXC1 & $6 \mathrm{p} 25.3$ & Anterior segment dysgenesis \\
\hline$A T X N 2$ & $12 q 24.12$ & Neurodegeneration \\
\hline GAS7 & $17 \mathrm{p} 13$ & CA, IOP changes \\
\hline GALC & $14 q 31.3$ & Increased POAG risk \\
\hline
\end{tabular}

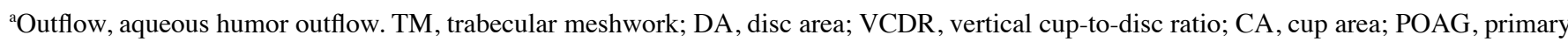
open angle glaucoma; RNFL, retinal nerve fiber layer.

and signal transduction (37). CAV1 and CAV2 are found to be expressed in ciliary muscle, TM, Schlemm's canal and retinal cells, and variants in the $C A V 1 / C A V 2$ region are associated with IOP changes, possibly through alterations of aqueous 


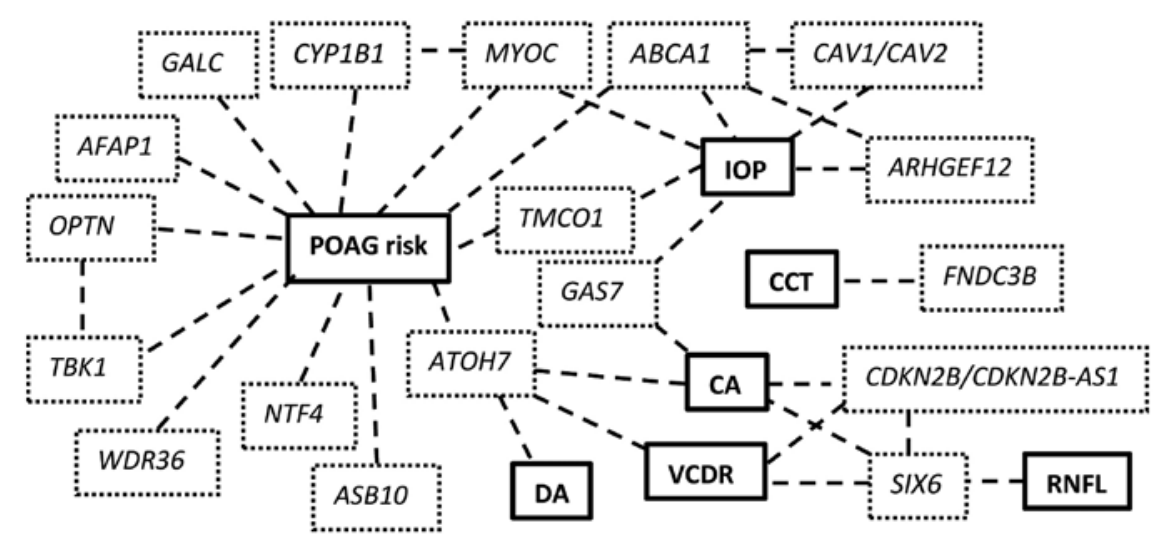

Figure 1. Common variants and their associations to POAG risk and/or endophenotypes and interactions. POAG, primary open-angle glaucoma; IOP, intraocular pressure; CCT, central corneal thickness; CA, cup area; DA, disc area; VCDR, vertical cup-to-disc ratio; RNFL, retinal nerve fiber layer.

outflow resistance (37-39). A possible direct, cell type specific interaction of $C A V 1$ with ATP-binding cassette, subfamily A, member 1 ( $A B C A 1)$, also supports a possible role in POAG $(40)$.

Cyclin-dependent kinase inhibitor $2 B$ antisense RNA 1 $(C D K N 2 B-A S 1)$. Located on chromosome $9 \mathrm{p} 21$, in the $C D K N 2 B-C D K N 2 A$ gene cluster, $C D K N 2 B$ protein is expressed in the inner nuclear layers of the retina and the ganglion cell layer. $C D K N 2 B-A S 1$ is detected in the retina, ciliary body and optic nerve and variants have been associated with VCDR changes and NTG especially in women, as well as various non-ocular disorders, namely myocardial infarction and intracranial aneurysms; an association of POAG risk and these conditions has not been made however (41-47).

Six homeobox 6 (SIX6). Located on chromosome 14q23, SIX6 gene encodes homeobox proteins, critical for ocular development. The protein encoded by this gene is a homeobox protein that is similar to the Drosophila 'sine oculis' gene product and is thought to be involved in eye development. Variants in this locus have been linked to POAG through VCDR, myopia and reduced retinal nerve fiber layer (RNFL) thickness. An interesting interaction of the POAG-risk His141 SIX6 variant with $C D K N 2 B-A S 1$ has been proposed as the former has been shown to elevate expression of the latter. A possibly protective Asn141 SIX6 variant remains to be further observed $(44,47,48-52)$.

Transmembrane and coiled-coil domains protein 1 (TMCO1). Located on chromosome 1q24.1, TMCO1 encodes a transmembrane protein playing a key role in calcium homeostasis. It is expressed, among other ocular tissues, in the TM and retina. Sequence variants have been associated with IOP and increased POAG risk to a degree of 1.7-fold per risk allele, making it a significant quantitative trait $(46,50,53-55)$.

$A B C A 1$. Located on chromosome $9 \mathrm{q} 31, A B C A 1$ encodes a protein complex associated with extracellular and intracellular membrane transport. Although the locus is mainly associated with familial high-density lipoprotein deficiency and Tangier's disease, $A B C A 1$ is also expressed in numerous ocular tissues, namely TM, ciliary body and RGCs. Sequence variants have been linked to POAG and IOP, possibly through an inflammatory and neurodegenerative mechanism $(56,57)$.
Actin filament-associated protein 1 (AFAP1). Located on chromosome 4p16.1, AFAPl encodes an adaptor protein that modulates changes in actin filament integrity in response to cellular signals. It is expressed, among others, in the retina and TM cells. Sequence variants have been associated with POAG through a still unknown mechanism $(41,57)$.

RHO guanine nucleotide exchange factor 12 (ARHGEF12). Located on chromosome 11q23.3, ARHGEF12 encodes a guanine nucleotide exchange factor (GEF) that may form a complex with $\mathrm{G}$ proteins and stimulate Rho-dependent signals. An intronic variant has been associated with POAG and IOP, possibly through activation of RhoA and subsequent ROCK activation, leading to decreased outflow and elevated IOP. An interesting interaction is that with $A B C A l$ protein, with ARHGEF 12 preventing $A B C A 1$ degradation (58-60).

Thioredoxin reductase 2 (TXNRD2). Located on chromosome 22q11, TXNRD2 gene encodes a mitochondrial protein important for scavenging reactive oxygen species in mitochondria. It belongs to the family of flavoenzymes that catalyze redox reactions, thus controlling the levels of reactive oxygen species. TXNRD2 is found, among others, in the retina and optic nerve and sequence variants have been associated with POAG, possibly through a protective effect of TXNRD2 against oxidative stress of the RGCs $(41,61,62)$.

Forkhead box C1 (FOXC1). Located on chromosome 6p25.3, FOXC1 is found next to GDP-mannose 4,6-dehydratase $(G M D S)$ gene. It encodes a protein that has been shown to play a role in the regulation of embryonic and ocular development. Although mainly linked to anterior segment dysgenesis and Axenfeld-Rieger syndrome, sequence variants within the $G M D S$ gene as well as variants located upstream of $F O X C 1$ have been associated with POAG $(41,57)$.

Ataxin 2 (ATXN2). Located on chromosome 12q24.12, ATXN2 is involved in regulating mRNA translation through its interactions with the poly (A)-binding protein. It is also involved in the formation of stress granules and P-bodies, which also play roles in RNA regulation (63). ATXN2 is expressed, among others, in the ciliary body, retina, and optic nerve. Although mainly linked to spinocerebellar ataxia and ALS, variants in 
ATXN2 have been associated with POAG possibly through neurodegeneration $(41,64)$.

Growth arrest-specific 7 (GAS7). Located on chromosome $17 \mathrm{p} 13$, GAS7 encodes a protein that plays a putative role in neuronal development as well as maturation and is primarily expressed in vivo, in terminally differentiated brain cells. GAS7 has been associated with increased cup volume and $\operatorname{IOP}(47,54,55,65)$.

Galactosylceramidase (GALC). Located on chromosome 14q31.3, GALC encodes a lysosomal enzyme called galactosylceramidase, which is mainly linked to Krabbe disease, a rare disorder of the myelin sheath with progressive optic neuropathy. GALC has been associated with a 5-fold increased risk of POAG when heterozygous for a $\mathrm{CNV}$ deletion $(66,67)$.

\section{Additional genes associated with POAG}

Single SNPs in the MYOC, COL8A2, COL1A1 and ZNF469 gene regions have shown marginal association with POAG in a study conducted in South Africa (68). Although the number of the subjects enrolled in the study was small, it was demonstrated that the main POAG-associated susceptibility alleles found in other populations, play a reduced role in populations of African ancestry. Moreover, a GWAS performed in India identified a novel candidate gene for POAG, called membrane palmitoylated protein 7 (MPP7), which is dysregulated under cyclic mechanical stress in the TM, thus causing dysfunction of cell to cell interaction (69), while another study in India led to an novel association of POAG with Opticin (OPTC) gene (70).

\section{Endophenotypes and clinical association}

Endophenotypes are stable, heritable quantitative traits, disease independent, that are usually helpful in analysing heterogeneous or variably phenotypic diseases. For POAG, these traits include IOP, CCT, VCDR, DA and RNFL thickness and as mentioned, contribute separately in the heritability of the disease (14). Studying the Endophenotypes helped dissect the disease and focus on separate components that are linked to clinical practice; nonetheless the variety of POAG endophenotypes highlights the complexity of the disease (Fig. 1).

IOP. Independent of the genetic component, IOP remains the only modifiable risk factor and IOP reduction the most commonly used treatment of POAG. Of the aforementioned genetic variants, TMCO1, CAV1/CAV2, ARHGEF12, ABCA1 and GAS7 have been linked to IOP through GWAS, among other susceptibility loci $(43,54,55)$. Of great interest is that the combined heritability of these loci regarding IOP is less than $2 \%$, meaning that the majority is still to be explained (55). This observation could mean that further investigating the IOP endophenotype could clarify its role in glaucoma both as a contributing factor and a therapeutic target.

$C C T$. Well recognized as an independent risk factor for POAG, over 26 loci have been identified for CCT $(3,71)$. With a highly heritable trait, CCT shows association with ethnicity, with lower values in populations of African descent $(11,72)$. Of the many sequence variants identified for CCT, of interest is fibronectin type III domain-containing protein 3B (FNDC 3B) which appears to be involved also in IOP changes (71).

$V C D R$. Increased VCDR is one of the cardinal clinical signs of glaucomatous optic neuropathy. Of the above mentioned genetic variants, $A T O H 7, C D K N 2 B$-AS1 and SIX6 have been linked to VCDR, among other susceptibility loci $(73,74)$.

$D A$ and $C A$. For DA 14 loci have been identified, 5 of which are also associated with VCDR. Of these, perhaps the most interesting is $A T O H 7$, associated with DA, CA and VCDR, that appears to affect the differentiation of the RGCs $(35,73,74)$. Approximately 27 variants have been associated with CA, notably ATOH7, CDKN2B-AS1 and SIX6 which, as mentioned previously, have also been linked to $\operatorname{VCDR}(49,75)$.

$R N F L$. Two susceptibility loci have been identified for RNFL thickness through linkage analysis. As previously discussed, a SIX6 coding variant is one of them $(51,76)$.

\section{Conclusion}

Since the turn of the century there has been an explosion of research using genetic and next generation, high-throughput DNA sequencing technologies and it is unquestionably expected that they will be extensively employed also for further investigation and diagnosis of glaucoma. We aimed to present the basic role of the most studied sequence variants regarding POAG and their complex interaction. Although many more have been identified and many remain to be further clarified, linkage analysis initially and, recently, GWAS, have opened the road to the admittedly enigmatic and heterogenic disease that is POAG. As regards the issue of genetic counselling, genetic testing for glaucoma may obviously be helpful in some specific situations, such as screening of family members with a known genetic mutation in autosomal dominant POAG of early onset, although at a population level this is not presently justified (77).

With various components and differential clinical expression, the identification of genetic factors either directly linked to the disease or endophenotype-related, brings us closer to understanding the molecular and cellular mechanisms and, eventually, to the development of efficient therapeutic approaches targeted at the root cause of the condition.

\section{Acknowledgements}

Not applicable.

\section{Funding}

No funding was received.

\section{Availability of data and materials}

Not applicable. 


\section{Authors' contributions}

AT, ETD, GNG, DAS and MIZ conceived and designed the study. AT, GNG and ETD researched the literature, performed critical analysis and review of the literature and drafted the manuscript. DAS and MIZ critically revised the article for important intellectual content. All authors read and approved the final manuscript.

\section{Ethics approval and consent to participate}

Not applicable

\section{Patient consent for publication}

Not applicable.

\section{Competing interests}

The authors declare that they have no competing interests. DAS is the Editor-in-Chief for the journal, but had no personal involvement in the reviewing process, or any influence in terms of adjudicating on the final decision, for this article.

\section{References}

1. Tham YC, Li X, Wong TY, Quigley HA, Aung T and Cheng CY: Global prevalence of glaucoma and projections of glaucoma burden through 2040: A systematic review and meta-analysis. Ophthalmology 121: 2081-2090, 2014.

2. Kwon YH, Fingert JH, Kuehn MH and Alward WL: Primary open-angle glaucoma. N Engl J Med 360: 1113-1124, 2009.

3. Gordon MO, Beiser JA, Brandt JD, Heuer DK, Higginbotham EJ, Johnson CA, Keltner JL, Miller JP, Parrish RK II, Wilson MR, et al: The Ocular Hypertension Treatment Study: Baseline factors that predict the onset of primary open-angle glaucoma. Arch Ophthalmol 120: 714-720, discussion 829-830, 2002.

4. Fan BJ, Leung YF, Wang N, Lam SC, Liu Y, Tam OS and Pang CP: Genetic and environmental risk factors for primary open-angle glaucoma. Chin Med J (Engl) 117: 706-710, 2004.

5. Wolfs RC, Klaver CC, Ramrattan RS, van Duijn CM, Hofman A and de Jong PT: Genetic risk of primary open-angle glaucoma. Population-based familial aggregation study. Arch Ophthalmol 116: 1640-1645, 1998.

6. Stone EM, Fingert JH, Alward WL, Nguyen TD, Polansky JR, Sunden SL, Nishimura D, Clark AF, Nystuen A, Nichols BE, et al: Identification of a gene that causes primary open angle glaucoma. Science 275: 668-670, 1997.

7. Rezaie T, Child A, Hitchings R, Brice G, Miller L, Coca-Prados M, Héon E, Krupin T, Ritch R, Kreutzer D, et al Adult-onset primary open-angle glaucoma caused by mutations in optineurin. Science 295: 1077-1079, 2002.

8. Monemi S, Spaeth G, DaSilva A, Popinchalk S, Ilitchev E, Liebmann J, Ritch R, Héon E, Crick RP, Child A, et al: Identification of a novel adult-onset primary open-angle glaucoma (POAG) gene on 5q22.1. Hum Mol Genet 14: 725-733, 2005.

9. Pasutto F, Matsumoto T, Mardin CY, Sticht H, Brandstätter JH, Michels-Rautenstrauss K, Weisschuh N, Gramer E, Ramdas WD, van Koolwijk LM, et al: Heterozygous NTF4 mutations impairing neurotrophin-4 signaling in patients with primary open-angle glaucoma. Am J Hum Genet 85: 447-456, 2009.

10. Fingert JH: Primary open-angle glaucoma genes. Eye (Lond) 25 : 587-595, 2011.

11. Charlesworth J, Kramer PL, Dyer T, Diego V, Samples JR, Craig JE, Mackey DA, Hewitt AW, Blangero J and Wirtz MK: The path to open-angle glaucoma gene discovery: Endophenotypic status of intraocular pressure, cup-to-disc ratio, and central corneal thickness. Invest Ophthalmol Vis Sci 51: 3509-3514, 2010.
12. Klein BE, Klein R and Lee KE: Heritability of risk factors for primary open-angle glaucoma: The Beaver Dam Eye Study. Invest Ophthalmol Vis Sci 45: 59-62, 2004.

13. Sanfilippo PG, Hewitt AW, Hammond CJ and Mackey DA: The heritability of ocular traits. Surv Ophthalmol 55: 561-583, 2010.

14. Liu Y and Allingham RR: Major review: Molecular genetics of primary open-angle glaucoma. Exp Eye Res 160: 62-84, 2017.

15. Liu Y and Allingham RR: Molecular genetics in glaucoma. Exp Eye Res 93: 331-339, 2011.

16. Sheffield VC, Stone EM, Alward WL, Drack AV, Johnson AT, Streb LM and Nichols BE: Genetic linkage of familial open angle glaucoma to chromosome 1q21-q31. Nat Genet 4: 47-50, 1993.

17. Fingert JH, Héon E, Liebmann JM, Yamamoto T, Craig JE, Rait J, Kawase K, Hoh ST, Buys YM, Dickinson J, et al: Analysis of myocilin mutations in 1703 glaucoma patients from five different populations. Hum Mol Genet 8: 899-905, 1999.

18. Kaur K, Reddy AB, Mukhopadhyay A, Mandal AK, Hasnain SE, Ray K, Thomas R, Balasubramanian D and Chakrabarti S: Myocilin gene implicated in primary congenital glaucoma. Clin Genet 67: 335-340, 2005.

19. Dismuke WM, Challa P, Navarro I, Stamer WD and Liu Y: Human aqueous humor exosomes. Exp Eye Res 132: 73-77, 2015.

20. Kaur K, Mandal AK and Chakrabarti S: Primary congenital glaucoma and the involvement of CYP1B1. Middle East Afr J Ophthalmol 18: 7-16, 2011.

21. Aung T, Rezaie T, Okada K, Viswanathan AC, Child AH, Brice G, Bhattacharya SS, Lehmann OJ, Sarfarazi M and Hitchings RA: Clinical features and course of patients with glaucoma with the E50K mutation in the optineurin gene. Invest Ophthalmol Vis Sci 46: 2816-2822, 2005.

22. Cirulli ET, Lasseigne BN, Petrovski S, Sapp PC, Dion PA, Leblond CS, Couthouis J, Lu YF, Wang Q, Krueger BJ, et al; FALS Sequencing Consortium: Exome sequencing in amyotrophic lateral sclerosis identifies risk genes and pathways. Science 347: 1436-1441, 2015.

23. Heo JM, Ordureau A, Paulo JA, Rinehart J and Harper JW: The PINK1-PARKIN mitochondrial ubiquitylation pathway drives a program of OPTN/NDP52 recruitment and TBK1 activation to promote mitophagy. Mol Cell 60: 7-20, 2015.

24. Slowicka K, Vereecke L and van Loo G: Cellular functions of optineurin in health and disease. Trends Immunol 37: 621-633, 2016.

25. Park BC, Tibudan M, Samaraweera M, Shen X and Yue BYJT: Interaction between two glaucoma genes, optineurin and myocilin. Genes Cells 12: 969-979, 2007.

26. Morton S, Hesson L, Peggie M and Cohen P: Enhanced binding of TBK1 by an optineurin mutant that causes a familial form of primary open angle glaucoma. FEBS Lett 582: 997-1002, 2008.

27. Liu Y, Garrett ME, Yaspan BL, Bailey JC, Loomis SJ, Brilliant M, Budenz DL, Christen WG, Fingert JH, Gaasterland D, et al: DNA copy number variants of known glaucoma genes in relation to primary open-angle glaucoma. Invest Ophthalmol Vis Sci 55: 8251-8258, 2014b.

28. Gijselinck I, Van Mossevelde S, van der Zee J, Sieben A, Philtjens S, Heeman B, Engelborghs S, Vandenbulcke M, De Baets G, Bäumer V, et al; BELNEU Consortium: Loss of TBK1 is a frequent cause of frontotemporal dementia in a Belgian cohort. Neurology 85: 2116-2125, 2015.

29. Matsumoto G, Shimogori T, Hattori $\mathrm{N}$ and Nukina N: TBK1 controls autophagosomal engulfment of polyubiquitinated mitochondria through p62/SQSTM1 phosphorylation. Hum Mol Genet 24: 4429-4442, 2015.

30. Janssen SF, Gorgels TG, Ramdas WD, Klaver CC, van Duijn CM, Jansonius NM and Bergen AA: The vast complexity of primary open angle glaucoma: Disease genes, risks, molecular mechanisms and pathobiology. Prog Retin Eye Res 37: 31-67, 2013.

31. Kramer PL, Samples JR, Monemi S, Sykes R, Sarfarazi M and Wirtz MK: The role of the WDR36 gene on chromosome $5 \mathrm{q} 22.1$ in a large family with primary open-angle glaucoma mapped to this region. Arch Ophthalmol 124: 1328-1331, 2006.

32. Gallenberger M, Meinel DM, Kroeber M, Wegner M, Milkereit P, Bösl MR and Tamm ER: Lack of WDR36 leads to preimplantation embryonic lethality in mice and delays the formation of small subunit ribosomal RNA in human cells in vitro. Hum Mol Genet 20: 422-435, 2011.

33. Murakami K, Meguro A, Ota M, Shiota T, Nomura N, Kashiwagi K, Mabuchi F, Iijima H, Kawase K, Yamamoto T, et al: Analysis of microsatellite polymorphisms within the GLC1F locus in Japanese patients with normal tension glaucoma. Mol Vis 16: 462-466, 2010. 
34. Pasutto F, Keller KE, Weisschuh N, Sticht H, Samples JR, Yang YF, Zenkel M, Schlötzer-Schrehardt U, Mardin CY, Frezzotti P, et al: Variants in ASB10 are associated with open-angle glaucoma. Hum Mol Genet 21: 1336-1349, 2012.

35. Macgregor S, Hewitt AW, Hysi PG, Ruddle JB, Medland SE, Henders AK, Gordon SD, Andrew T, McEvoy B, Sanfilippo PG, et al: Genome-wide association identifies ATOH7 as a major gene determining human optic disc size. Hum Mol Genet 19: 2716-2724, 2010 .

36. Venturini C, Nag A, Hysi PG, Wang JJ, Wong TY, Healey PR, Mitchell P, Hammond CJ and Viswanathan AC; Wellcome Trust Case Control Consortium 2, BMES GWAS Group: Clarifying the role of ATOH7 in glaucoma endophenotypes. Br J Ophthalmol 98: 562-566, 2014

37. Gu X, Reagan AM, McClellan ME and Elliott MH: Caveolins and caveolae in ocular physiology and pathophysiology. Prog Retin Eye Res 56: 84-106, 2017.

38. Chen F, Klein AP, Klein BE, Lee KE, Truitt B, Klein R, Iyengar SK and Duggal P: Exome array analysis identifies CAV1/CAV2 as a susceptibility locus for intraocular pressure. Invest Ophthalmol Vis Sci 56: 544-551, 2014.

39. Aga M, Bradley JM, Wanchu R, Yang YF, Acott TS and Keller KE: Differential effects of caveolin-1 and -2 knockdown on aqueous outflow and altered extracellular matrix turnover in caveolin-silenced trabecular meshwork cells. Invest Ophthalmol Vis Sci 55: 5497-5509, 2014.

40. Kuo CY, Lin YC, Yang JJ and Yang VC: Interaction abolishment between mutant caveolin-1 $(\Delta 62-100)$ and $A B C A 1$ reduces HDL-mediated cellular cholesterol efflux. Biochem Biophys Res Commun 414: 337-343, 2011.

41. Bailey JN, Loomis SJ, Kang JH, Allingham RR, Gharahkhani P, Khor CC, Burdon KP, Aschard H, Chasman DI, Igo RP Jr, et al ANZRAG Consortium: Genome-wide association analysis identifies TXNRD2, ATXN2 and FOXC1 as susceptibility loci for primary open-angle glaucoma. Nat Genet 48: 189-194, 2016.

42. Burdon KP, Crawford A, Casson RJ, Hewitt AW, Landers J, Danoy P, Mackey DA, Mitchell P, Healey PR and Craig JE: Glaucoma risk alleles at CDKN2B-AS1 are associated with lower intraocular pressure, normal-tension glaucoma, and advanced glaucoma. Ophthalmology 119: 1539-1545, 2012

43. Chen Y, Hughes G, Chen X, Qian S, Cao W, Wang L, Wang M and Sun X: Genetic variants associated with different risks for high tension glaucoma and normal tension glaucoma in a Chinese population. Invest Ophthalmol Vis Sci 56: 2595-2600, 2015.

44. Wiggs JL, Yaspan BL, Hauser MA, Kang JH, Allingham RR, Olson LM, Abdrabou W, Fan BJ, Wang DY, Brodeur W, et al: Common variants at $9 \mathrm{p} 21$ and $8 \mathrm{q} 22$ are associated with increased susceptibility to optic nerve degeneration in glaucoma. PLoS Genet 8: e1002654, 2012.

45. Kathiresan S, Voight BF, Purcell S, Musunuru K, Ardissino D, Mannucci PM, Anand S, Engert JC, Samani NJ, Schunkert H, et al; Wellcome Trust Case Control Consortium: Genome-wide association of early-onset myocardial infarction with single nucleotide polymorphisms and copy number variants. Nat Genet 41: 334-341, 2009

46. Burdon KP, Macgregor S, Hewitt AW, Sharma S, Chidlow G, Mills RA, Danoy P, Casson R, Viswanathan AC, Liu JZ, et al: Genome-wide association study identifies susceptibility loci for open angle glaucoma at TMCO1 and CDKN2B-AS1. Nat Genet 43: 574-578, 2011.

47. Shiga Y, Nishiguchi KM, Kawai Y, Kojima K, Sato K, Fujita K, Takahashi M, Omodaka K, Araie M, Kashiwagi K, et al: Genetic analysis of Japanese primary open-angle glaucoma patients and clinical characterization of risk alleles near CDKN2B-AS1, SIX6 and GAS7. PLoS One 12: e0186678, 2017.

48. Carnes MU, Liu YP, Allingham RR, Whigham BT, Havens S, Garrett ME, Qiao C, Katsanis N, Wiggs JL, Pasquale LR, et al NEIGHBORHOOD Consortium Investigators: Discovery and functional annotation of SIX6 variants in primary open-angle glaucoma. PLoS Genet 10: e1004372, 2014

49. Iglesias AI, Springelkamp H, van der Linde H, Severijnen LA Amin N, Oostra B, Kockx CE, van den Hout MC, van Ijcken WF Hofman A, et al: Exome sequencing and functional analyses suggest that SIX6 is a gene involved in an altered proliferation-differentiation balance early in life and optic nerve degeneration at old age. Hum Mol Genet 23: 1320-1332, 2014.

50. Burdon KP, Mitchell P, Lee A, Healey PR, White AJ, Rochtchina E, Thomas PB, Wang JJ and Craig JE: Association of open-angle glaucoma loci with incident glaucoma in the Blue Mountains Eye study. Am J Ophthalmol 159: 31-36.e1, 2015.
51. Kuo JZ, Zangwill LM, Medeiros FA, Liebmann JM, Girkin CA, Hammel N, Rotter JI and Weinreb RN: Quantitative trait locus analysis of SIX1-SIX6 with retinal nerve fiber layer thickness in individuals of European descent. Am J Ophthalmol 160: 123-130.e1, 2015.

52. Skowronska-Krawczyk D, Zhao L, Zhu J, Weinreb RN, Cao G, Luo J, Flagg K, Patel S, Wen C, Krupa M, et al: P16INK4a Upregulation mediated by SIX6 defines retinal ganglion cell pathogenesis in glaucoma. Mol Cell 59: 931-940, 2015

53. Scheetz TE, Faga B, Ortega L, Roos BR, Gordon MO, Kass MA, Wang $\mathrm{K}$ and Fingert JH: Glaucoma risk alleles in the ocular hypertension treatment study. Ophthalmology 123: 2527-2536, 2016.

54. van Koolwijk LM, Ramdas WD, Ikram MK, Jansonius NM, Pasutto F, Hysi PG, Macgregor S, Janssen SF, Hewitt AW, Viswanathan AC, et al; DCCT/EDIC Research Group; Wellcome Trust Case Control Consortium 2: Common genetic determinants of intraocular pressure and primary open-angle glaucoma. PLoS Genet 8: e1002611, 2012.

55. Hysi PG, Cheng CY, Springelkamp H, Macgregor S, Bailey JNC, Wojciechowski R, Vitart V, Nag A, Hewitt AW, Höhn R, et al; BMES GWAS Group; NEIGHBORHOOD Consortium; Wellcome Trust Case Control Consortium 2: Genome-wide analysis of multi-ancestry cohorts identifies new loci influencing intraocular pressure and susceptibility to glaucoma. Nat Genet 46: 1126-1130, 2014.

56. Chen Y, Lin Y, Vithana EN, Jia L, Zuo X, Wong TY, Chen LJ, Zhu X, Tam PO, Gong B, et al: Common variants near ABCA1 and in PMM2 are associated with primary open-angle glaucoma. Nat Genet 46: 1115-1119, 2014

57. Gharahkhani P, Burdon KP, Fogarty R, Sharma S, Hewitt AW, Martin S, Law MH, Cremin K, Bailey JNC, Loomis SJ, et al; Wellcome Trust Case Control Consortium 2, NEIGHBORHOOD consortium: Common variants near ABCA1, AFAP1 and GMDS confer risk of primary open-angle glaucoma. Nat Genet 46: $1120-1125,2014$

58. Springelkamp H, Iglesias AI, Cuellar-Partida G, Amin N, Burdon KP, van Leeuwen EM, Gharahkhani P, Mishra A, van der Lee SJ, Hewitt AW, et al: ARHGEF12 influences the risk of glaucoma by increasing intraocular pressure. Hum Mol Genet 24: 2689-2699, 2015.

59. Lessey-Morillon EC, Osborne LD, Monaghan-Benson E, Guilluy C, O'Brien ET, Superfine R and Burridge K: The RhoA guanine nucleotide exchange factor, LARG, mediates ICAM-1-dependent mechanotransduction in endothelial cells to stimulate transendothelial migration. J Immunol 192: 3390-3398, 2014.

60. Okuhira K, Fitzgerald ML, Tamehiro N, Ohoka N, Suzuki K, Sawada J, Naito $M$ and Nishimaki-Mogami T: Binding of PDZ-RhoGEF to ATP-binding cassette transporter A1 (ABCA1) induces cholesterol efflux through RhoA activation and prevention of transporter degradation. J Biol Chem 285: 16369-16377, 2010.

61. Chen Y, Cai J and Jones DP: Mitochondrial thioredoxin in regulation of oxidant-induced cell death. FEBS Lett 580: 6596-6602, 2006.

62. Caprioli J, Munemasa Y, Kwong JM and Piri N: Overexpression of thioredoxins 1 and 2 increases retinal ganglion cell survival after pharmacologically induced oxidative stress, optic nerve transection, and in experimental glaucoma. Trans Am Ophthalmol Soc 107: 161-165, 2009.

63. Orr HT: Cell biology of spinocerebellar ataxia. J Cell Biol 197: 167-177, 2012.

64. Lattante S, Millecamps S, Stevanin G, Rivaud-Péchoux S, Moigneu C, Camuzat A, Da Barroca S, Mundwiller E, Couarch P, Salachas F, et al; French Research Network on FTD and FTD-ALS: Contribution of ATXN2 intermediary polyQ expansions in a spectrum of neurodegenerative disorders. Neurology 83: 990-995, 2014.

65. Ju YT, Chang ACY, She BR, Tsaur ML, Hwang HM, Chao CCK, Cohen SN and Lin-Chao S: gas7: A gene expressed preferentially in growth-arrested fibroblasts and terminally differentiated Purkinje neurons affects neurite formation. Proc Natl Acad Sci USA 95: 11423-11428, 1998.

66. Wenger DA, Rafi MA,Luzi P, Datto J and Costantino-Ceccarini E: Krabbe disease: Genetic aspects and progress toward therapy. Mol Genet Metab 70: 1-9, 2000.

67. Liu Y, Gibson J, Wheeler J, Kwee LC, Santiago-Turla CM, Akafo SK, Lichter PR, Gaasterland DE, Moroi SE, Challa P, et al: GALC deletions increase the risk of primary open-angle glaucoma: The role of Mendelian variants in complex disease. PLoS One 6: e27134, 2011. 
68. Williams SE, Carmichael TR, Allingham RR, Hauser M and Ramsay M: The genetics of POAG in black South Africans: A candidate gene association study. Sci Rep 5: 8378, 2015.

69. Vishal M, Sharma A, Kaurani L, Alfano G, Mookherjee S, Narta K, Agrawal J, Bhattacharya I, Roychoudhury S, Ray J, et al: Genetic association and stress mediated down-regulation in trabecular meshwork implicates MPP7 as a novel candidate gene in primary open angle glaucoma. BMC Med Genomics 9: 15, 2016.

70. Acharya M, Mookherjee S, Bhattacharjee A, Thakur SK, Bandyopadhyay AK, Sen A, Chakrabarti S and Ray K: Evaluation of the OPTC gene in primary open angle glaucoma: functional significance of a silent change. BMC Mol Biol 8: 21, 2007.

71. Lu Y, Vitart V, Burdon KP, Khor CC, Bykhovskaya Y, Mirshahi A, Hewitt AW, Koehn D, Hysi PG, Ramdas WD, et al NEIGHBOR Consortium: Genome-wide association analyses identify multiple loci associated with central corneal thickness and keratoconus. Nat Genet 45: 155-163, 2013.

72. Chua J, Tham YC, Liao J, Zheng Y, Aung T, Wong TY and Cheng CY: Ethnic differences of intraocular pressure and central corneal thickness: The Singapore Epidemiology of Eye Diseases study. Ophthalmology 121: 2013-2022, 2014.

73. Ramdas WD, van Koolwijk LME, Ikram MK, Jansonius NM, de Jong PTVM, Bergen AAB, Isaacs A, Amin N, Aulchenko YS, Wolfs RC, et al: A genome-wide association study of optic disc parameters. PLoS Genet 6: e1000978, 2010.
74. Springelkamp H, Höhn R, Mishra A, Hysi PG, Khor CC, Loomis SJ, Bailey JN, Gibson J, Thorleifsson G, Janssen SF, et al; Blue Mountains Eye Study-GWAS group; NEIGHBORHOOD Consortium; Wellcome Trust Case Control Consortium 2 (WTCCC2): Meta-analysis of genome-wide association studies identifies novel loci that influence cupping and the glaucomatous process. Nat Commun 5: 4883, 2014.

75. Springelkamp H, Iglesias AI, Mishra A, Höhn R, Wojciechowski R, Khawaja AP, Nag A, Wang YX, Wang JJ, Cuellar-Partida G, et al; NEIGHBORHOOD Consortium: New insights into the genetics of primary open-angle glaucoma based on meta-analyses of intraocular pressure and optic disc characteristics. Hum Mol Genet 26: 438-453, 2017.

76. Axenovich T, Zorkoltseva I, Belonogova N, van Koolwijk LM, Borodin P, Kirichenko A, Babenko V, Ramdas WD, Amin N, Despriet DD, et al: Linkage and association analyses of glaucoma related traits in a large pedigree from a Dutch genetically isolated population. J Med Genet 48: 802-809, 2011.

77. Khawaja AP and Viswanathan AC: Are we ready for genetic testing for primary open-angle glaucoma? Eye (Lond) 32: 877-883, 2018.

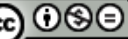

\footnotetext{
This work is licensed under a Creative Commons Attribution-NonCommercial-NoDerivatives 4.0 International (CC BY-NC-ND 4.0) License.
} 